\title{
PENGEMBANGAN INSTRUMEN TES TINGKAT LITERASI STATISTIS SISWA
}

\author{
Delyanti Azzumarito Pulungan ${ }^{* 1}$, Mila Yulia Herosian ${ }^{1}$ \\ ${ }^{1}$ Program Studi Manajemen Ekonomi, Universitas Prima Indonesia \\ *Email korespondensi: delyantiazzumaritopulungan@unprimdn.ac.id
}

\begin{abstract}
ABSTRAK
Penelitian ini bertujuan untuk mengembangkan tes melek statistik. Tes ini valid pada konten, valid pada konstruk, dan dapat diandalkan untuk mengukur dan menilai literasi statistik siswa. Literasi statistik dikembangkan melalui 3 tahap pengembangan yaitu: pendahuluan, perencanaan, dan pengembangan. Validitas isi Literasi Statistis dilakukan dengan penilaian ahli, validitas konstruk dianalisis dengan metode analisis faktor konfirmatori dua tingkat berdasarkan kriteria Goodness Of Fit serta reliabilitas model dianalisis menggunakan construct reliability. Hasil validitas konstruk menunjukkan bahwa setiap item dapat diukur secara signifikan oleh 6 aspek Literasi Statistis. Model konseptual literasi statistik berada dalam kategori good fit, dengan nilai RMSEA 0,023, CFI 0, 91 dan GFI 1, 00, ini berarti bahwa model literasi statistik good fit. Hasil uji reliabilitas model yang dilihat dari nilai construct validity, diperoleh nilai sebesar Literasi Statistis ini diuji pada 150 siswa SMA di Kota Medan. Hasil uji reliabilitas konstruk diperoleh nilai construct reliability (CR) setiap variable lates sebesar 0,83 $\geq 0,70$ dan nilai Variance Extracted $(V E)$ sebesar 0,61 $\geq 0,5$. Berdasarkan nilai CR dan VE, maka konstruk Literasi Statistis siswa berada pada kategori reliabilitas konstruk yang baik.
\end{abstract}

Kata kunci: Literasi Statistis, Analisis Faktor Komfirmatori dua tingkat, Pengembangan Instrumen.

\begin{abstract}
This study aims to develop statistical literacy tests. This test is valid content, valid construct, and reliable to measure and assess student statistical literacy. Statistical literacy is developed through 3 stages of development: introduction, planning, and development. The validity of the contents of the statistical literacy is done by expert judgment, the construct validity is analyzed by the two-level confirmatory factor analysis method based on the Goodness Of Fit criteria and the model reliability is analyzed using construct reliability. The results of construct validity show that each item can be measured significantly by 6 aspects of statistical literacy. The conceptual model of statistical literacy is in the good fit category, with RMSEA values of 0.023, CFI 0, 91 and GFI 1, 00, this means that the model of statistical literacy is good fit. The model reliability test results seen from the construct validity value, obtained a value of statistical literacy was tested to 150 high schools students in Medan. The results of the construct reliability test obtained the value of construct reliability (CR) for each lates variable of $0.83 \geq 0.70$ and the Variance Extracted (VE) value of $0.61 \geq 0.5$. Based on $\mathrm{CR}$ and VE values, the statistical literacy construct of students is in the category of good construct reliability.
\end{abstract}

Keywords: Statistical Literacy, $2^{\text {nd }}$ Order Factor Comfirmatory Analysis, Test Development 


\section{PENDAHULUAN}

Literasi Statistis menjadi tujuan penting pendidikan matematika baik berdasarkan standar kurikulum KTSP 2006 maupun Kurikulum 2013. Tiro \& Nusrang (2016: 705) menjelaskan bahwa pembelajaran statistika menekankan pada literasi statistik yang memandang statistika tidak hanya penyajian bilangan dalam bentuk angka tetapi juga memandang bilangan bersama konteksnya. Sayangnya, paradigma bahwa pembelajaran statistika masih dipengaruhi cara tradisional, dimana statistika merupakan bagian dari pembelajaran matematika. Lebih lanjut, Tiro \& Nusrang (2016) menjelaskan bahwa anggapan statistika yang dipengaruhi cara tradisional disebabkan oleh dua faktor. Pertama, anggapan statistika merupakan bagian dari matematika yang masih menekankan paradigm matematis, yaitu statistika diajarkan sebagai metode atau prosedur teknis, tanpa memberi penekanan perhatian pada makna di balik angka yang dihasilkan dari analisis data. Kedua, pembelajaran statistika masih warisan dari cara tradisional yang belum memanfaatkan teknologi informasi seperti komputer, internet, dan software.

Statistika merupakan mathematical science tetapi bukan merupakan cabang matematika, dengan karakteristik berfikir yang lebih spesifik dibandingkan dengan teori matematis. Statistika dapat dipandang sebagai pengetahuan tentang variabilitas dan menjadi sebuah sarana untuk menerangkan fenomena ketidakpastian yang senantiasa terjadi di dalam kehidupan, di tempat kerja, dan di dalam ilmu pengetahuan itu sendiri (Moore, 1997). Secara khusus statistika digunakan untuk menguraikan dan memprediksi fenomena yang memerlukan kumpulan hasil dari pengukuran (Dasari, 2006).

Garfield (2002) menjelaskan bahwa Literasi Statistis adalah kemampuan individu melakukan penafsiran, evaluasi secara kritis, dan berkomunikasi terkait informasi dan pesan statistik. Informasi dan pesan statistis yang dimaksud oleh Garfield meliputi: kata, simbol, istilah, serta mampu membuat dan menafsirkan grafik, tabel, mampu membaca dan memahami statistik dalam berita, media elektronik, jajak pendapat, dan sumber-sumber lainnya. Pendapat ini sejalan dengan yang dikemukakan oleh Gal (2002) bahwa Literasi Statistis merupakan kemampuan orang untuk menafsirkan, mengevaluasi secara kritis informasi statistik dalam data berbasis argumen yang muncul di saluran berbagai media dan kemampuan mereka dalam membahasnya. Pandangan lain menjelaskan bahwa Literasi Statistis merupakan kemampuan untuk mengekstrak informasi kualitatif dari informasi kuantitatif, dan membuat informasi baru 
dari data kualitatif dan kuantitatif tersebut (Aoyama \& Stephens, 2003). Hafiyusholeh (2015) menyatakan bahwa literasi statistik penting bagi siswa karena pada akhirnya siswa akan dihadapkan pada perannya sebagai produsen atau konsumen data. Sebagai produsen data, seseorang harus memahami cara menyajikan data sehingga data yang dihasilkan mudah untuk dibaca dan dipahami oleh orang lain. Ainley, et.al dalam penelitiannya menjelaskan bahwa kemampuan siswa dalam menginterpretasikan data yang sajiannya dalam bentuk grafik masih merupakan sesuatu yang dianggap sulit.

Berdasarkan Permendikbud No. 24 Tahun 2016, kemampuan yang berkaitan dengan kompetensi dasar pada materi statistika yaitu: a) menganalisis data, nilai rata-rata, median dan modus, dan sebaran data untuk mengambil simpulan, membuat keputusan, dan membuat prediksi, b) menyajikan dan menyelesaikan masalah yang berkaitan dengan distribusi data, nilai rata-rata, median, modus, dan sebaran data untuk mengambil simpulan, membuat keputusan, dan membuat prediksi. Berdasarkan berbagai pendapat ahli, dapat disimpulkan bahwa Literasi Statistis merupakan kemampuan individu untuk membaca serta memahami, melakukan analisis yang kemudian melakukan interpretasi hasil lalu melakukan evaluasi sehingga dapat dikomunikasikan kepada publik guna menyelesaikan berbagai permasalahn sehari-hari menggunakan pendekatan statistik.

Dasari (2006) dalam tulisannya mengemukakan dua arah bentuk pembaharuan mempengaruhi proses belajar mengajar statistika untuk semua level pendidikan. Pertama, pembaharuan yang berfokus pada aspek konten dan aspek pedagogis, hal ini ditandai dengan beralihnya fokus yang bersifat komputatif dan prosedural ke arah penekanan pada penalaran dan berfikir statistis (Moore, 1997). Kedua, pembaharuan dalam lingkup asesmen siswa, hal ini ditandai dengan memperjelas tujuan-tujuan belajar serta penggunaan asesmen sebagai alat untuk memperbaiki belajar siswa (Garfield, 1993; Chance \& Garfield, 2002). Berbagai pendekatan pedagogis telah banyak dilakukan oleh guru pada pembelajaran statistik. Melalui berbagai pendekatan pembelajaran aktif-kolaboratif, sampai dengan memanfaatkan teknologi baik dalam mereduksi data, membaca data, memahami data, menganalisis bahkan melakukan interpretasi. Sayangnya, assessmen yang dilakukan untuk menilai tingkat Literasi Statistis siswa masih sangat terbatas.

Penelitian yang dilakukan oleh Nishfani, Kusmanto dan Akbar pada tahun 2017 yang meninjau tingkat Literasi Statistis siswa SMA menunjukkan indikator kemampuan literasi 
statistik, kemampuan menggambarkan statistik memiliki presentase paling tinggi dibandingkan dengan indikator lainnya, sedangkan kemampuan dengan hasil yang paling rendah adalah kemampuan mengidentifikasi permasalahan statistik dianggap siswa lebih sulit (Nishfani, Kusmanto, \& Akbar, 2017). Sehingga, dapat diartikan bahwa siswa memiliki hasil kemampuan literasi statistik yang kurang. Penelitian lainnya yang dilakukan Maryati dan Priatna (2018) yang meninjau kemampuan Literasi Statistis siswa Madrasah Tsanawiyah menunjukkan Hasil analisis data menunjukkan kemampuan siswa dalam membaca data statistika yang diberikan dalam bentuk tabel, diagram dan grafik sebesar 35\%, kemampuan siswa dalam memahami konsep sebesar 32\%, kemampuan siswa dalam mengkomunikasikan proses pengolahan data sebesar 30\%, serta kemampuan siswa dalam mempresentasikan hasil pengolahan data sebesar $28 \%$. Adapun kesimpulan dari analisis tersebut dapat dikategorikan rendah karena masih berada di bawah kriteria ketuntasan minimum.

Penelitian-penelitian yang telah dilakukan selama ini terbatas hanya pada bagaimana kemampuan siswa mengerjakan soal-soal statistika, padahal dalam mengidentifikasi tingkat kemampuan siswa, maka instrumen penilaian yang digunakan harus memiliki kualitas yang baik dan tepat dalam mengukur Literasi Statistis. Karena itu, penting sekali disusun sebuah instrumen yang dapat mengukur dan melakukan penilaian atas kemampuan Literasi Statistis siswa. Wawancara yang dilakukan kepada 3 guru bidang studi matematika tingka SMP dan SMA diperoleh informasi bahwa pembelajaran statistika telah dilakukan dengan berbagai jenis pendekatan pembelajaran, namun saat ditanya tentang bagaimana guru mengukur Literasi Statistis siswa, guru kesulitan menjawab. Bahkan, informasi tentang Literasi Statistis yang dimiliki guru juga sangat sedikit. Karena itu, ketika di tanya tentang bagaimana mereka mengetahui tingkat Literasi Statistis siswa, guru tidak mampu menjelaskan.

Fakta lapangan juga ditemukan dari wawancara kepada guru di bidang studi matematika tingkat SMP dan SMA bahwa selama ini mereka hanya mengukur kemampuan statistis siswa dari soal-soal yang ada di buku pembelajaran matematika pada materi statistik. Tanpa melakukan pengukuran berdasarkan indicator konseptual yang menjadi konstruk kemampuan Literasi Statistis. Oleh karena itu, pengembangan instrumen tes tingkat Literasi Statistis pada penelitian ini menjadi hal yang baru dan sangat penting dilakukan. 


\section{METODE PENELITIAN}

Penelitian ini adalah penelitian mixed methode dengan desain Research and Development (R \& D). Adapun yang dikembangkan dalam penelitian ini adalah instrumen tes Literasi Statistis siswa. Model pengembangan penelitian dibagi menjadi 3 tahap: Pendahuluan, Perencanaan dan Pengembangan. Subjek uji coba adalah siswa berusia minimal 15 tahun, atau setingkat SMA Kelas X di Kota Medan sebanyak 150 siswa. Jumlah sampel ini mengacu saran Hair et al (1998) yang mensyaratkan minimal jumlah sampelnya sebesar 5 - 10 kali variabel indikator. Indikator variabel pada penelitian ini ada sebanyak 12, sehingga jumlah 150 cukup bisa dikatakan memenuhi kriteria. Uji validitas isi instrumen oleh 5 orang ahli. Pengujian unidimensionalitas (validitas dan reliabilitas) setiap variabel laten dengan menggunakan Confirmatory Factor Analysis (CFA): menggunakan criteria Goodness Of Fit (GOF), dan uji realibilitas model dengan pendekatan construct reliability.

\section{HASIL DAN PEMBAHASAN}

\section{Tahap 1: Pendahuluan}

\section{Analisis Kebutuhan}

Hasil analisis kebutuhan guru menunjukkan bahwa persepsi dan keinginan guru untuk meningkatkan kemampuan statistik siswa, khususnya dalam membaca data sangat tinggi. Guru mempunyai pandangan yang positif untuk meningkatkan kompetensi siswa dalam memahami, membaca dan menginterpretasi data. Selain itu guru juga berkeinginan positif agar siswa dapat menyelesaiakan berbagai konteks kehidupan sehari-hari melalui konsep statistik. Keinginan positif itu ternyata belum didukung dengan pengalaman guru dalam mengembangkan instrumen tes yang mampu mengukur seberapa tingkat Literasi Statistis siswa. Selama ini guru masih hanya menggunakan soal-soal statistik langsung dari buku. Hal ini bisa jadi disebabkan bahwa guru masih mempunyai pengalaman yang terbatas dalam mengembangkan instrumen penilaian.

\section{Telaah Konseptual Literasi Statistis}

Tahap ini melakukan telaah konsep atau teori tentang indikator ukur Literasi Statistis untuk mengembangkan model hipotetik dari Literasi Statistis. Telaah dilakukan berdasarkan konsep Literasi Statistis siswa, kompetensi pembelajaran statistik siswa yang masuk pada 
pembelajaran matematika pada jenjang SMP Kelas VIII pada kurikulum 2013, serta berdasarkan konteks yang dekat dengan siswa usia sekolah SMA.

\section{Tahap 2: Perencanaan}

\section{Prototipe Instrumen Tes Literasi Statistis}

Instrumen tes Literasi Statistis dikembangkan berdasarkan 6 faktor indicator yang terdiri dari: membaca data, memahami data, melakukan analisis menggunakan konsep statistis, melakukan interpretasi data/hasil statistis, melakukan evaluasi terhadap data / hasil statistis dan mengkomunikasikan data / informasi statistis. Masing-masing indikator diukur oleh 2 butir. Sehingga diperoleh 12 butir ukur Literasi Statistis siswa.

\section{Jenis dan bentuk Instrumen Tes Literasi Statistis}

Tes Literasi Statistis yang dikembangkan berbentuk essay. Jenis tes dipilih karena Literasi Statistis akan melihat aspek kognitif dari Literasi Statistis siswa. Bentuk butir essai dipilih karena butir essai akan menampilkan penjelasan proses penyelesaian masalah statistis yang diketahui oleh siswa.

\section{Tahap 3: Pengembangan}

\section{Model Hipotetik Instrumen Tes Literasi Statistis}

Pada tahap ini, butir-butir ukur Literasi Statistis disusun menjadi sebuah perangkat tes Literasi Statistis siswa. Perangkat tes lengkap dengan bagian identitas peserta tes serta petunjuk pengerjaan tes.

\section{Rubrik Penskoran}

Pada tahap ini disusun rubrik penskoran sebagai panduan pengukuran hasil ujicoba tes Literasi Statistis siswa, dapat dilihat pada Tabel 1.

Tabel 1. Kriteria Penskoran

\begin{tabular}{lc}
\hline No & Kriteria \\
\hline 0 & Tidak Menjawab \\
1 & Menjawab salah, tanpa proses dan penjelasan \\
2 & Menjawab salah, ada proses dan penjelasan \\
3 & Menjawab benar, tanpa proses dan penjelasan \\
4 & Menjawab benar, ada proses dan penjelasan \\
\hline
\end{tabular}

Sumber: Hasil Olah Data Penelitian, 2019 


\section{Telaah Hipotetik Oleh Ahli (Expert Jugdment)}

Model hipotetik instrumen tes Literasi Statistis kemudian diuji valid isinya oleh 5 ahli (expert judgment) dengan menggunakan angket validitas isi expert berdasarkan analisis rasional oleh expert. Angket terdiri dari 5 aspek penilaian, teridiri dari : 1. Apakah Indikator sudah sesuai dengan Defenisi Konseptual Literasi Statistis siswa? 2. Apakah butir tes Literasi Statistis siswa sudah sesuai dengan Indikator ? 3. Apakah tujuan / maksud butir sudah dirumuskan dengan tepat dan jelas? 4. Apakah Instruksi tes telah dituliskan dengan jelas? 5. Apakah butir sesuai dengan pembelajaran statistika untuk siswa sekolah? Analisis validitas isi instrument dilakukan menggunakan indeks validitas, Aiken (1980; 1985; Kumaidi, 2014). Hasil indeks validitas Aiken berdasarkan 5 orang ahli, dapat dilihat pada Tabel 2.

Tabel 2. Indeks Validitas Aiken Ahli

\begin{tabular}{lcc}
\hline \multicolumn{1}{c}{ Kriteria } & Indeks Validitas Aiken (V) kelima Ahli \\
\hline $\begin{array}{l}\text { Kesesuaian Indikator dengan Definisi } \\
\text { konseptual Literasi Statistis siswa }\end{array}$ & 0,80 \\
$\begin{array}{l}\text { Kesesuaian butir dengan indicator ukur Literasi } \\
\text { Statistis siswa }\end{array}$ & 0,93 \\
$\begin{array}{l}\text { Ketepatan dan kejelasan dalam merumuskan } \\
\text { butir tes Literasi Statistis siswa }\end{array}$ & 0,93 \\
$\begin{array}{l}\text { Kejelasan instruksi pengerjaan tes Literasi } \\
\text { Statistis siswa }\end{array}$ & 0,87 \\
$\begin{array}{l}\text { Kesesuaian butir tes Literasi Statistis dengan } \\
\text { pembelajaran statistika sekolah }\end{array}$ & 0,80 \\
\hline
\end{tabular}

Sumber: Hasil Olah Data Penelitian, 2019

Indeks V ini nilainya berkisar diantara 0-1. Dari hasil perhitungan indeks $\mathrm{V}$, suatu butir dikategorikan berdasarkan indeksnya. Jika $\mathrm{V} \leq 0,4$ dikatakan validitasnya kurang, jika 0,4 > V $\leq 0,8$ dikatakan validitasnya sedang, dan jika $\mathrm{V}>0,8$ dikatakan sangat valid. (Retnawati, 2016). Berdasarkan hasil analisis indeks Aiken, diperoleh data bahwa untuk setiap kategori, indeks validitas isi setiap butir memiliki $\mathrm{V}>0,8$, sehingga dapat disimpulkan bahwa intrumen tes Literasi Statistis siswa berada pada validitas tinggi.

\section{Ujicoba Perseorangan (One-to-one)}

Ujicoba one-to-one dilakukan kepada 3 orang siswa SMA. Data keterbacaan tes oleh siswa dilakukan dengan menggunakan angket keterbacaan siswa. Berdasarkan ujicoba one to 
one, diperoleh kesimpulan bahwa tingkat keterbacaan instrument ada pada kategori "Baik", tetapi tetap ada catatan perbaikan berdasarkan diskusi dengan siswa. Catatan perbaikan terkait dengan: 1) ada kesalahan penulisan pada butir 3, 5, dan 8 meskipun tetap bias dipahami; 2) ada butir yang menampilakan grafik dan diagram, tetapi kurang jelas keterangannya. Selain itu, pada ujicoba one-to-one juga diperoleh data waktu yang dibutuhkan untuk mengerjakan instrumen tes Literasi Statistis menghasilkan informasi bahwa rerata waktu yang dibutuhkan untuk menyelesaikan tes Literasi Statistis adalah sebanyak 82 menit, atau sekitar 7-8 menit per butir. Berdasarkan itu diambil kesimpulan untuk mengerjakan 12 butir tes Literasi Statistis, siswa diberikan waktu sebanyak 90 menit.

\section{Ujicoba Instrumen Tes Literasi Statistis}

Ujicoba dilakukan kepada 200 orang siswa dari 2 sekolah yang berbeda. Ujicoba dilakukan untuk memperoleh data hasil tes siswa yang akan dianalisis validitas konstruk dengan teknik analisis Second Order Confirmatory Factor Analysis dengan bantuan software. Analisis data dilakukan dengan kriteria nilai muatan faktor $(>0.5)$ dan nilai t hitung $(>1,96)$ yang hasilnya dapat dilihat pada Tabel 3.

Tabel 3. Hasil Nilai Estimasi, Nilai t, dan Standardize Indikator

\begin{tabular}{cccccc}
\hline Variabel & Indikator & $\begin{array}{c}\text { Estimasi } \\
(\lambda)\end{array}$ & Nilai t & $\begin{array}{c}\text { Standardize } \\
\text { Estimasi }\end{array}$ & $\begin{array}{c}\text { Keterangan } \\
\text { (signifikan/ tidak) }\end{array}$ \\
\hline Membaca Data & BD1 & & & 0,82 & Signifikan \\
Memahami Data & BD2 & 0,57 & 8,81 & 0,80 & Signifikan \\
& PD1 & & & 0,86 & Signifikan \\
Analisis Data & PD2 & 0.60 & 10.94 & 0,89 & Signifikan \\
& AD2 & 0.62 & 8.47 & 0,82 & Signifikan \\
Interpretasi Data & ID1 & & & 0,87 & Signifikan \\
& ID2 & 0.73 & 7.94 & 0,86 & Signifikan \\
Evaluasi Data & ED1 & & & 0,87 & Signifikan \\
& ED2 & 0.68 & 7.27 & 0,85 & Signifikan \\
Komunikasi Data & KD1 & & & 0,81 & Signifikan \\
& KD2 & 0.55 & 6.02 & 0,83 & Signifikan \\
\hline
\end{tabular}

Sumber: Hasil Olah Data Penelitian, 2019 
Tingkat kedua analisis dilakukan dari konstruk laten ke konstruk aspeknya. Berdasarkan hasil pengujian di atas menunjukkan bahwa nilai loading faktor semuanya $>0,5$ dan semua nilai t hitung yang diperlukan untuk menguji signifikansi nilai loading faktor lebih besar dari 1,96. Rangkuman hasil analisis tersebut dapat dilihat pada Tabel 4.

Tabel 4. Hasil Nilai Estimasi, Nilai t Variabel Literasi Statistis

\begin{tabular}{lccl}
\hline \multicolumn{1}{c}{ Variabel } & Estimasi $(\lambda)$ & Nilai t & Keterangan \\
\hline Membaca Data & 0,67 & 6,81 & Signifikan \\
Memahami Data & 0.78 & 10.44 & Signifikan \\
Analisis Data & 0.72 & 9.47 & Signifikan \\
Interpretasi Data & 0.83 & 12.94 & Signifikan \\
Evaluasi Data & 0.75 & 10.27 & Signifikan \\
\hline Komunikasi Data & 0.60 & 5.02 & Signifikan \\
\hline
\end{tabular}

Sumber: Hasil Olah Data Penelitian, 2019

Berdasarkan hasil dapat dilihat bahwa ujicoba secara konseptual telah sesuai dengan teori yang diestimasikan 6 faktor yaitu: (1) membaca Data, (2) memahami data, (3) analisis data, (4) interpretasi data, (5) evaluasi data, (6) komunikasi data. Berdasarkan hasil ujicoba diperoleh informasi bahwa variabel yang paling dominan mengukur Literasi Statistis adalah variabel interpretasi data dengan nilai estimasi sebesar 0.83 dengan nilai t sebesar 12,94.

Kecocokan model dilihat dari nilai RMSEA, CFI dan GFI (Ghazali, 2012) yang diperlihatkan pada Tabel 5.

Tabel 5. Hasil Kriteria Goodness of Fit

\begin{tabular}{cllll}
\hline No. & Kriteria & Nilai Hitung & Nilai Kritis & Kategori \\
\hline 1. & RMSEA & 0,023 & $<0,05$ & Close fit \\
2. & CFI & 1,00 & $>0,90$ & Good fit \\
\hline 3. & GFI & 1,00 & $>0,90$ & Good fit \\
\hline
\end{tabular}

Sumber: Hasil Olah Data Penelitian, 2019

Hasil uji kecocokan model (Goodnes of Fit) menunjukkan bahwa berdasarkan nilai RMSEA, CFI dan GFI yang dihasilkan mengkategori bahwa instrumen tes aLiterasi Statistis yang dikembangkan memiliki model dengan kategori good fit. Di mana nilai RMSEA sebesar 
$0.023<0.05$ yang berarti model close fit. Nilai CFI sebesar 1,00>0.90 yang berarti good fit, dan nilai GFI sebesar 1,00 > 0.90 yang berarti good fit (Ghozali, 2014). Berdasarkan perolehan data itu maka disimpulkan bahwa model konstruk intrumen Literasi Statistis yang dikembangkan masuk pada kategori good fit.

Selain melihat validitas konstruk, tes Literasi Statistis yang dikembangkan juga dianalisis relibilitasnya. Hasil analisis reliabilitas model contruct reliability $(C R)$ dan nilai Variance extracted (VE) diperoleh hasil bahwa setiap indikator reliabel dalam mengukur variabel laten. Hasil uji reliabilitas konstruk diperoleh nilai construct reliability $(C R)$ setiap variabel laten sebesar 0,83 $\geq 0,70$ dan nilai Variance extracted (VE) sebesar 0,61 $\geq 0,5$.

Dengan memperhatikan analisis tersebut, informasi yang diperoleh adalah bahwa bentuk tes yang valid konstruk dan reliabel konstruk dalam mengukur Literasi Statistis siswa, karena terbukti model konseptual Literasi Statistis yang dikembangkan memenuhi kategori good fit. Variabel memahami data dan interpretasi data menjadi variabel yang dominan mengukur Literasi Statistis.

\section{KESIMPULAN}

Penelitian ini telah menghasilkan perangkat tes Literasi Statistis siswa. Hasil penelitian menunjuukkan bahwa bahwa semua indikator signifikan (dapat mengukur) terhadap variabel laten membaca data, memahami data, analisis data, interpretasi data, evaluasi data dan komunikasi data. Ini bermakna bahwa keenam kompetensi Literasi Statistis siswa secara signifikan dapat mengukur Literasi Statistis siswa. Dengan begitu, instrumen tes Literasi Statistis yang dihasilkan dari penelitian digunakan untuk mengukur kemampuan Literasi Statistis siswa Interpretasi data adalah factor yang berperan paling kuat dan nyata mengukur Literasi Statistis siswa.

\section{REKOMENDASI}

Konseptual pengembangan Instrumen Literasi Statistis siswa yang diperoleh dari hasil penelitian ini, dapat dijadikan rujukan bagi guru untuk mengembangkan soal literasi statistis yang dapat digunakan untuk mengukur kemampuan Literasi Statistis siswa. Dalam proses pembelajaran statistis, guru juga dapat menggunakan keenam variabel ukur Literasi Statistis sebagai acuan dalam membelajarkan materi statistik bagi siswa di sekolah. Hasil penelitian ini 
juga dapat digunakan sebagai evaluasi bagi guru dalam memperbaiki pembelajaran, terutama proses penilaian pembelajaran statistik siswa di sekolah. Hasil penelitian tes literasi statistik pada penelitian ini masih memiliki banyak aspek yang perlu diteliti oleh peneliti selanjutnya. Sehingga dapat saling melengkapi khasanah konseptual dan kompetensi literasi statistik siswa.

\section{UCAPAN TERIMAKASIH}

Penelitian ini terlaksana atas dukungan dana dari Kementerian Riset dan Pendidiakn Tinggi melalui Program Penelitian Dosen Pemula. Oleh karena itu, ucapan terima kasih yang sebesarnya kepada Ristek Dikti atas dukungan dana sehingga penelitian dapat diselesaikan dengan baik. Ucapan terima kasih juga kepada Reviewer yang membantu penyempurnaan artikel hasil penelitian ini. Tidak lupa kepada Tim Editor Publisher Jurnal sehingga artikel hasil laporan penelitian ini dapat diterbitkan. Serta kepada LPPM Universitas Prima Indonesia yang mendukung pelaksanaan penelitian ini.

\section{REFERENSI}

Aiken, L, R. (1980). Content validity and reliability of single items or questionaires. Educational and Psychological Measurement, 40, 955-967.

Aiken, L, R. (1985). Three coefficients for analyzing the reliability and validity of ratings. Educational and Psychological Measurement, 45, 131-142.

Aoyama, K., \& Stephens, M. (2003). Graph interpretation aspects of statistical literacy: A Japanese perspective. Mathematics Education Research Journal, 15(3), 207-225. https://doi.org/10.1007/BF03217380.

Dasari, D. (2006). Kemampuan Literasi Statistis dan Implikasinya dalam Pembelajaran. Seminar Nasional Matematika Dan Pendidikan Matematika, 1-9.

Gal, I. (2002). Adults ' Statistical literacy: Meanings, Components, Responsibilities. International Statistical Review, 70(1), 1-51.

Garfield, J. (2002). The challenge of developing statistical reasoning. Journal of Statistics Education, 10(3), http://www.amstat.org/publications/jse/v10n3/garfield.html.

Ghozali, I. (2014). Structural Equation Modeling - Metode Alternatif dengan Partial Least Squares (PLS). Universitas Diponegoro. Semarang.

Hafiyusholeh, M. (2015). Literasi Statistik dan Urgensinya Bagi Siswa. Wahana, 64(1), 1-8.

Hair, J.F. et. al. 1998. Multivariate Data Analysis. 5th Edition. Prentice Hall International, New Jersey. 
Kumaidi. (2014). Validitas dan pemvalidasian instrumen penilaian karakter. Makalah disampaikan dalam Seminar Nasional Pengembangan Instrumen Penilaian Pendidikan Karakter yang valid, diselenggarakan Fakultas Psikologi, Universitas Muhammadiyah Surakarta, 24 Mei 2014.

Maryati, I., \& Priatna, N. (2018). Analisis Kemampuan Literasi Statistis Siswa Madrasah Tsanawiyah dalam Materi Statistika. Journal of Medives: Journal of Mathematics Education IKIP Veteran Semarang, 205. https://doi.org/10.31331/medives.v2i2.640.

Moore, D. S. (1997). [New Pedagogy and New Content: The Case of Statistics]: Response. International Statistical Review / Revue Internationale de Statistique, 65(2), 162. https://doi.org/10.2307/1403341.

Nishfani, N., Kusmanto, H., \& Akbar, R. O. (2017). The Use of Big Data for Education \& Kontribusi Matematika dalam Mempertahankan Nilai Budaya dan Sastra ANALISIS TINGKAT KEMAMPUAN LITERASI STATISTIK SISWA SMA SEDERAJAT BERDASARKAN MUTU SEKOLAH. Prosiding PROCEDIAMATH, 33-47.

Permendikbud. (2016). Peraturan Menteri Pendidikan dan Kebudayaan tentang Kompetensi Inti dan Kompetensi Dasar. Jakarta.

Tiro, M. A., \& Nusrang, M. (2016). Eksplorasi Pembelajaran Literasi Statistika Dalam Paradigma Konstruktivisme. In Seminar Nasional Matematika dan Statistika (SEMASTAT) (pp. 705-715). Padang: Universitas Negerti Padang. 